\title{
High intraspecific genetic and morphological variation in the pioneer lichen Cladonia rei colonising slag dumps
}

Research Article

\author{
${ }^{1}$ Department of Polar Research and Documentation, Institute of Botany, \\ Jagiellonian University, 31-501 Kraków, Poland \\ ${ }^{2}$ Department of Plant Taxonomy, Phytogeography and Herbarium, \\ Institute of Botany, Jagiellonian University, 31-501 Kraków, Poland \\ ${ }^{3}$ Department of Microbiology, University of Agriculture in Kraków, \\ 30-059 Kraków, Poland \\ ${ }^{4}$ Department of Forest Pathology, University of Agriculture in Kraków, \\ 31-425 Kraków, Poland
}

Piotr Osyczka1,", Kaja Rola², Anna Lenart-Boroń ${ }^{3}$, Piotr Boroń ${ }^{4}$

Received 13 August 2013; Accepted 15 November 2013

Abstract: This study investigates the genetic and morphological variability of the lichen Cladonia rei inhabiting strongly contaminated postsmelting slag dumps in southern Poland. Altogether, 27 C. rei samples were analysed, including 17 from a single population in one dump. The phylogenetic analysis includes samples of $C$. rei, outgroup species, and external sequences of Cladonia section representatives from GenBank. Comparative analysis of the internal transcribed spacer (ITS) rDNA sequences revealed the presence of $19 \mathrm{C}$. rei haplotypes overall, including several of the most frequent, of which 11 are represented by single individuals only. As many as 12 haplotypes were recorded within a single population. Three strongly supported monophyletic clades comprised of specimens from different geographical regions were recovered. Morphometric analysis showed great phenotypic variability within particular clades. Apart from a full range of previously known morphological forms of the species, an additional specific morphotype was recognised in the dumps; however, its representatives do not create a monophyletic group. High genetic variability within a single population suggests that $C$. rei has a great potential for colonising anthropogenic habitats. This attribute emphasises the role of this lichen as an essential pioneer in the early stages of natural regeneration of such sites.

Keywords: Cladonia • Lichenized Ascomycota - Genetic variation • Phylogenetic analysis • ITS • Haplotype • Morphometric analysis - Anthropogenic habitat

(c) Versita Sp. z 0.0.

\section{Introduction}

Lichens, as highly specialised symbiotic organisms, colonise extreme habitats, where they are frequently successful in outperforming vascular plants and even bryophytes in terms of biodiversity and also biomass [1]. They are effective and rapid colonisers of bare ground and their pioneer nature is associated not only with natural sites, but also anthropogenic and artificial habitats. Some lichen species have modest ecological requirements and thus are capable of rapid and effective colonisation of disturbed sites [2,3]. This attribute raises important questions about the dispersal abilities of particular lichens and their consequences in the form of intraspecific genetic variability within a population.

Molecular investigations of lichen-forming fungi have considerably advanced in the last decades, especially in the context of their taxonomy and phylogeny (see [4]). Contrastingly, studies at the population level are still far less common (e.g. [5]; see also [6]). Some recent molecular studies have demonstrated intraspecific variation in certain widespread lichens (e.g. $[1,7,8]$ ). Nevertheless, there is still much to learn about local genetic diversity in lichen populations and their response to anthropogenic changes. Moreover, the genetic structure of populations may hold information 
essential for understanding population dynamics [6]. Genetic structure results from four processes: mutation, drift, selection, and gene flow [9]. The genetic variation within a single population of lichens may be caused by external factors, e.g. geographical isolation, historical distribution, and mutagenic stress, as well as characteristics of the population itself, such as size, reproduction mode of individuals, number and type of propagules, and mating type (e.g. [6,7,10]). Even though data on the genetic relatedness of particular taxa/specimens of the genus Cladonia have been successfully used to resolve taxonomic problems (e.g. $[11,12])$, there is still little information on the level of genetic variation of the fungal component within a single population $[10,13,14]$. These two approaches provide an opportunity to obtain a broader view of the genetic diversity of traditionally recognised species and will be helpful in the interpretation of linkages obtained during molecular studies.

Our choice of model organism for this study was Cladonia rei Schaer., which is generally characterised by long and contorted podetia (secondary thallus) with partially corticated surfaces covered by farinose to granular soredia and squamules developing to various degrees. Cladonia rei, a typical epigeic lichen most frequently confined to dry and sunny places such as grasslands, heaths, and wastelands (see [15-17]), is an example of a heavy metal-tolerant species that grows in both contaminated and uncontaminated sites [18-22]. Although C. rei has been frequently used as a study object of molecular investigations in a taxonomic context $[11,17,23]$, genetic variation and population dynamics in this species are still poorly understood. Until recently, C. rei was considered to be rare in Poland [24]. This may be because it was overlooked and/or confused with morphologically similar species [15]. It is also possible that this species has spread intensely across the country. Interestingly, recent reports indicate that $C$. rei has great potential for rapid colonisation and successfully inhabits anthropogenic areas of postsmelting dumps, where it constitutes a main component of specific cryptogamic communities [25,26]. Therefore, investigations of the genetic diversity of $C$. rei within single populations appear to be promising approaches for determining their dynamics.

Our study focuses on an investigation of the genetic diversity of the fungal component of Cladonia rei, particularly in samples from a single population with specific and well-defined qualities, which inhabits a post-smelting dump. The following properties in particular deserve attention: the habitat of the entire population is artificially created and isolated from natural sites by urban areas; the population has been spontaneously colonising the area for no longer than the last 25 years; the population occupies an area that is small and homogenous in terms of habitat conditions; the individuals form a dense sward; most of the examined individuals have no apothecia, but all of them produce a large number of vegetative propagules. Keeping in mind all the aforementioned attributes, we tested the following hypothesis: relatively low genetic diversity should be a model for this type of population. Furthermore, our research aimed to answer the following important questions: 1) What is the genetic structure of the Cladonia rei mycobiont within a single population inhabiting an extremely contaminated and disturbed habitat? 2) Is expansive colonisation and mass occurrence of $C$. rei in post-smelting dumps associated with the existence of a specific ecotype/haplotype that is resistant or indifferent to extremely unfavourable habitat conditions? 3) Do the morphological/anatomical variability and chemical properties of $C$. rei coincide with a molecular pattern? Given that the spontaneous, rapid and abundant appearance of $C$. rei on extremely contaminated post-smelting dumps does not appear to be an accidental phenomenon (see $[25,26]$ ), we decided to find the answers to the aforementioned questions in order to better understand the colonisation success of this lichen in the context of its genetic pattern.

\section{Experimental Procedures}

\subsection{Study area and sampling}

Post-smelting dumps were created as a result of processing lead and zinc ores in the central part of the Upper Silesian Industrial Region, Poland. They consist entirely of man-made wastes, primarily deposited as slag, which has weathered over time into friable substrate or partially moulding sinters [27]. The dumps are an example of a strongly disturbed environment characterised by high concentrations of toxic elements $[25,28]$ and unfavourable habitat factors [29]. The most important physicochemical properties of the dumps are presented in Table 1. Lichen material was sampled in 2012 during a dry spring season. Altogether, 33 samples were collected (Table 2); the main examination refers to the population of Cladonia rei from one dump marked here as D1. The population occupies a small area of approximately 2,500 square metres. Additional samples of $C$. rei were gathered from three adjacent dumps (D2-D4) as well as two natural sites: the Pustynia Błędowska desert $\left(50^{\circ} 21^{\prime} \mathrm{N}, 19^{\circ} 30^{\prime} \mathrm{E}\right.$; ca. $\left.315 \mathrm{~m}\right)$ and the Gorce Mountains ( $49^{\circ} 58^{\prime} \mathrm{N}, 20^{\circ} 22^{\prime} \mathrm{E}$; ca. $750 \mathrm{~m}$ ). For comparative purposes, representatives of two outgroup species, Cladonia fimbriata (L.) Fr. and C. subulata (L.) F.H. Wigg., were also included in the study. Voucher 


\begin{tabular}{|c|c|c|c|c|}
\hline & Dump 1 & Dump 2 & Dump 3 & Dump 4 \\
\hline Location & $\begin{array}{c}\text { Piekary Śląskie } \\
50^{\circ} 21^{\prime} 11^{\prime \prime} \mathrm{N}, 18^{\circ} 58^{\prime} 00^{\prime \prime} \mathrm{E}\end{array}$ & $\begin{array}{c}\text { Piekary Śląskie } \\
50^{\circ} 20^{\prime} 34^{\prime \prime} \mathrm{N}, 18^{\circ} 58^{\prime} 28^{\prime \prime} \mathrm{E}\end{array}$ & $\begin{array}{c}\text { Piekary Śląskie } \\
50^{\circ} 21^{\prime} 53^{\prime \prime} \mathrm{N}, 18^{\circ} 58^{\prime} 03^{\prime \prime} \mathrm{E}\end{array}$ & $\begin{array}{c}\text { Świętochłowice } \\
50^{\circ} 19^{\prime} 05^{\prime \prime} \mathrm{N}, 18^{\circ} 54^{\prime} 13^{\prime \prime} \mathrm{E}\end{array}$ \\
\hline $\mathrm{pH}(\mathrm{KCl})$ & $7.1-7.2$ & $7.2-7.7$ & $7.8-7.9$ & $6.5-6.9$ \\
\hline C (\%) & $1.32-1.62$ & $1.67-3.75$ & $5.68-6.00$ & $8.40-9.95$ \\
\hline$N(\%)$ & $0.06-0.09$ & $0.15-0.16$ & $0.27-0.27$ & $0.26-0.30$ \\
\hline Ca/tot. $\left(\mu \mathrm{g} \mathrm{g}^{-1}\right)$ & $7275-12119$ & 4776-79812 & $133062-133625$ & 11200-14825 \\
\hline K/tot. $\left(\mu \mathrm{g} \mathrm{g}^{-1}\right)$ & 1983-2964 & 849-980 & 1073-1128 & $1136-1754$ \\
\hline Mg/tot. $\left(\mu \mathrm{g} \mathrm{g}{ }^{-1}\right)$ & $1422-4166$ & 17000-29827 & 18029-18378 & 10399-17945 \\
\hline P/tot. $\left(\mu \mathrm{g} \mathrm{g}^{-1}\right)$ & 2750-2862 & 556-1906 & 3700-3794 & 3525-4494 \\
\hline Zn/tot. $\left(\mu \mathrm{g} \mathrm{g}^{-1}\right)$ & 658-2233 & 12438-22356 & 31139-31635 & 41946-67216 \\
\hline Pb/tot. $\left(\mu \mathrm{g} \mathrm{g}^{-1}\right)$ & $328-728$ & 2338-3959 & 11680-11898 & 14236-23192 \\
\hline Cd/tot. $\left(\mu \mathrm{g} \mathrm{g}^{-1}\right)$ & $3-8$ & $6-50$ & $357-366$ & $78-86$ \\
\hline As/tot. $\left(\mu \mathrm{g} \mathrm{g}^{-1}\right)$ & 29-94 & 103-383 & $724-840$ & 2290-4424 \\
\hline
\end{tabular}

Table 1. Locations of the investigated post-smelting dumps and their basic chemical characteristics, based on chemical analyses of substrate samples $[25,26,59]$. Ranges of elements (min-max) for each dump are provided.

specimens are preserved in the KRA-L herbarium (Jagiellonian University, Kraków).

\subsection{DNA extraction, PCR amplification and DNA sequencing}

For each sample, DNA was extracted separately from a single, silica-dried podetium (ca. 20-50 mg) with a Genomic Mini AX Plant DNA extraction kit (A\&A Biotechnology, Poland), according to the manufacturer's protocol. DNA extracts were used as templates for PCR amplification of the ITS region with ITS1F [30] and ITS4 [31] primers. The total volume $(50 \mu \mathrm{l})$ of reaction mixture contained $1 \times$ Dream Taq reaction buffer, $2 \mathrm{mmol} \mathrm{L} \mathrm{L}^{-1} \mathrm{MgCl}_{2}$ (premixed with reaction buffer), $0.08 \mathrm{mmol} \mathrm{L}^{-1}$ of each dNTP, $0.08 \mu \mathrm{mol} \mathrm{L}^{-1}$ of both primers, $0.4 \mathrm{mg}$ of BSA, $1 \mathrm{U}$ of Dream Taq DNA polymerase (Thermo Scientific, Fermentas, Lithuania), and $5 \mu \mathrm{l}$ of template DNA. The reaction was run in a Veriti 96-Well Thermal Cycler (Applied Biosystems, Foster City, CA, USA) with the following temperature profile: 5 minutes of initial denaturation at $94^{\circ} \mathrm{C}, 25$ touchdown cycles with 30 seconds at $94^{\circ} \mathrm{C}, 30$ seconds at decreasing annealing temperatures $\left(0.5^{\circ}\right.$ cycle from $67.5^{\circ} \mathrm{C}$ in the 1 st to $55^{\circ} \mathrm{C}$ in the 25 th cycle), 1 minute at $72^{\circ} \mathrm{C}$ and 20 cycles with 30 seconds at $94^{\circ} \mathrm{C}, 30$ seconds at $55^{\circ} \mathrm{C}$, and 1 minute at $72^{\circ} \mathrm{C}$ followed by 10 minutes at $72^{\circ} \mathrm{C}$ as the final extension step. The PCR products were purified by agarose gel electrophoresis and retrieved from the gel with a Gel-Out kit (A\&A Biotechnology, Poland). The purified products were sequenced on both strands with complete overlap (Macrogen Europe, the Netherlands).
GenBank accession numbers for all newly obtained ITS sequences, including voucher specimen details, are listed in Table 2.

\subsection{Sequence alignment and phylogenetic analysis}

All newly obtained ITS sequences except for very short reads were analysed, along with GenBank ITS sequences of species belonging to section Cladonia selected according to Stenroos et al. [11], Dolnik et al. [17], and Pino-Bodas et al. [23]. A total number of 124 ITS sequences were analysed. The Cladonia rei sequence AF455191 [11] was used to designate the boundaries of the ITS region, and all sequences were trimmed to its length. The sequence alignment was generated with the ClustalW [32] algorithm implemented in the MEGA 5.1 software package [33] and corrected manually. As the areas with multiple differently ended gaps were revealed, the alignment positions with indels in more than one sequence were excluded due to uncertain nucleotide homology. However, the gaps were encoded as a binary matrix according to the simple indel coding method [34] with FastGap12 [35]. Both data sets, the sequence alignment without multiple indel sites and the gap matrix, were analysed jointly using Bayesian inference with MrBayes 3.1.2 [36]. The 50\% majority tree generated during the analysis was visualised in MEGA 5.1.

All 42 available Cladonia rei sequences containing no unidentified nucleotides were searched for the presence of individual haplotypes with Arlequin 3.11 [37], revealing the number, relative frequency, and connection 


\begin{tabular}{|c|c|c|c|c|}
\hline Species & Code & Chemotype & Collection & $\begin{array}{l}\text { GenBank } \\
\text { No. ITS }\end{array}$ \\
\hline \multirow{27}{*}{ C. rei } & D1-1 & $\|^{1}$ & \multirow{17}{*}{$\begin{array}{c}\text { Poland, Wyżyna Śląska upland, Piekary Śląskie town, Brzeziny Śląskie district, } \\
\text { post-smelting dump, 50²1' } 9.62^{\prime \prime} \text { N, } 18^{\circ} 57^{\prime} 54.96 \text { " E (center of studied } \\
\text { population), Osyczka \& Rola, 03.06.2012, KRA }\end{array}$} & KF525238 \\
\hline & D1-2 & $I^{1}$ & & KF525239 \\
\hline & D1-3 & $\|$ & & KF525240 \\
\hline & D1-4 & $\|$ & & KF525241 \\
\hline & D1-5 & $\|$ & & KF525242 \\
\hline & D1-6 & $\|$ & & KF525243 \\
\hline & D1-7 & $\|$ & & KF525244 \\
\hline & D1-8 & $\|$ & & KF525260 \\
\hline & D1-9 & $\|$ & & KF525245 \\
\hline & D1-10 & $\|$ & & KF525246 \\
\hline & D1-11 & 1 & & KF525247 \\
\hline & D1-12 & $\|$ & & KF525248 \\
\hline & D1-13 & $\|$ & & KF525249 \\
\hline & D1-14 & $\|$ & & KF525250 \\
\hline & D1-15 & 1 & & KF525258 \\
\hline & D1-16 & $\|$ & & KF525251 \\
\hline & D1-17 & $\|$ & & KF525252 \\
\hline & D2-1 & 1 & \multirow{4}{*}{$\begin{array}{l}\text { Poland, Wyżyna Śląska upland, Piekary Śląskie town, Brzeziny Śląskie district, } \\
\text { post-smelting dump, } \\
50^{\circ} 20^{\prime} 24.26^{\prime \prime} \text { N, } 18^{\circ} 58^{\prime} 24.42^{\prime \prime} \text { E, Osyczka \& Rola, 07.05.2011, KRA }\end{array}$} & KF525259 \\
\hline & D2-2 & 1 & & KF525237 \\
\hline & D2-3 & $\|$ & & KF525267 \\
\hline & D3-1 & $\|$ & & KF525253 \\
\hline & D3-2 & $\|$ & \multirow{3}{*}{$\begin{array}{c}\text { Poland, Wyżyna Śląska upland, Piekary Śląskie town, Brzozowice-Kamień } \\
\text { district, post-smelting dump, } 50^{\circ} 21^{\prime} 52.80^{\prime \prime} \text { N, } 18^{\circ} 57^{\prime} 58.55^{\prime \prime} \text { E Osyczka \& } \\
\text { Rola, 20.05.2012, KRA }\end{array}$} & KF525254 \\
\hline & D3-3 & $\|$ & & KF525255 \\
\hline & D3-4 & 1 & & KF525261 \\
\hline & D4-1 & 1 & $\begin{array}{c}\text { Poland, Wyżyna Śląska upland, Świętochłowice town, Lipiny district, } \\
\text { post-smelting dump, 50 18' 59.94" N, 18 54' 16.31" E, Osyczka \& Rola, } \\
\text { 22.05.2012, KRA }\end{array}$ & KF525257 \\
\hline & $\mathrm{BD}$ & 1 & $\begin{array}{l}\text { Poland, Wyżyna Śląska upland, Pustynia Błędowska desert, 50²0'37.74" N, } \\
\qquad 19^{\circ} 30^{\prime} 6.29^{\prime \prime} \text { E, Osyczka \& Rola, 15.06.2011, KRA }\end{array}$ & KF525268 \\
\hline & GNP & 1 & $\begin{array}{l}\text { Poland, Gorce Mts, Gorce NP, Kudłoń Mt., NW slope, alt. } 850 \text { m. a.s.l., Osyczka } \\
\text { \& Rola, 25.05.2010, KRA }\end{array}$ & KF525269 \\
\hline \multirow{5}{*}{ C. subulata } & $\mathrm{KL}-1$ & fumar. acid² & \multirow{2}{*}{$\begin{array}{c}\text { Poland, Wyżyna Śląska upland, Pustynia Błędowska desert, Klucze vill., } \\
\text { Osyczka \& Rola, 11.06.2012, KRA }\end{array}$} & KF525262 \\
\hline & $\mathrm{KL}-2$ & fumar. acid & & KF525263 \\
\hline & $\mathrm{BU}-1$ & fumar. acid & \multirow{2}{*}{$\begin{array}{l}\text { Poland, Wyżyna Krakowsko-Częstochowska upland, Bukowno vill., Osyczka \& } \\
\text { Rola, 11.06.2012, KRA }\end{array}$} & KF525264 \\
\hline & $\mathrm{BU}-2$ & fumar. acid & & KF525265 \\
\hline & $\mathrm{RS}$ & fumar. acid & $\begin{array}{l}\text { Poland, Wyżyna Śląska upland, Ruda Śląska town, Wirek district, Osyczka \& } \\
\text { Rola, 22.05.2012, KRA }\end{array}$ & KF525256 \\
\hline C. fimbriata & $\mathrm{CH}$ & fumar. acid ${ }^{3}$ & $\begin{array}{c}\text { Poland, Wyżyna Śląska upland, Pustynia Błędowska desert, Chechło vill., } \\
\text { Osyczka \& Rola, 22.05.2012, KRA }\end{array}$ & KF525266 \\
\hline
\end{tabular}

Table 2. GenBank accession numbers for newly sequenced Cladonia specimens.

$$
\begin{aligned}
& 1 \text { - after [17] } \\
& 2 \text { - fumarprotocetraric acid } \\
& 3 \text { - typical species' chemotype, see [60] }
\end{aligned}
$$

length between each haplotype required to generate the minimum spanning tree according to Rohlf's [38] algorithm. The tree was visualised with HapStar 0.7 [39] and corrected manually for a balanced shape.

\subsection{Morphological/anatomical and chemical analyses}

The samples were initially categorised by their morphology in accordance with the descriptions given by Syrek and Kukwa [15], James [16], and Dolnik et al.
[17]. The chemical composition of the lichen substances was analysed using thin layer chromatography (TLC), in solvent systems $\mathrm{C}$ and $\mathrm{G}$, following Orange et al. [40]. Subsequently, detailed morphological/anatomical measurements of particular specimens were performed. The following quantitative and qualitative features were assessed: podetium width, inter and outer medulla thickness, soredia size, presence of podetial squamules, podetial cortication, branching type, presence of scyphi, and presence of apothecia. 
The metric features were measured using Phenix Micro Image Analysis Software after appropriate scaling. The number of materials and units/scale used for particular measurements and observations are provided in Table 3.

\subsection{Statistical analysis}

Each specimen was treated as an Operational Taxonomic Unit (OTU), in accordance with the methods used in numerical taxonomy [41]. Prior to statistical analysis, the distribution normality of quantitative variables was verified using the Lilliefors test. Variables that did not meet the assumptions of normality were Box-Cox transformed to find the optimal normalising transformation for each variable. Podetium wall thickness (inner plus outer medulla thickness) and the proportion of inner to outer medulla thickness expressed as a ratio were used for further statistical analyses.

Firstly, all characteristics were analysed using cluster analysis to illustrate the general relationships and similarities between OTUs. This analysis was performed in order to obtain a general view of the results. This allowed determination of whether different morphological groups were separated into distinct clusters and assess the degree of diversity within groups. Moreover, the analysis was used to verify whether morphological groups of specimens corresponded to the designated phylogenetic clades or haplotypes. The similarity between two OTUs was calculated on the basis of Gower's general similarity coefficient. The dendrogram was prepared using the UPGMA method.

Subsequently, principal coordinate analysis (PCoA) was performed on the basis of all quantitative and qualitative features. The goal of PCoA was the positioning of objects (individuals) in a space of reduced dimensionality while preserving their distance relationships. The results of cluster analysis and PCoA were compared and interpreted.

The mean values of particular characteristics were calculated for each specimen. To reveal significant differences between the means of particular characteristics across all designated clades, a one-way analysis of variance (ANOVA) was performed. Levene's test was performed prior to the analysis to assess the equality of variances.

Data analyses and statistical calculations were performed using the STATISTICA (version 10; StatSoft Inc., http://www.statsoft.com), XLSTAT version 2013.1.02, and MVSP 3.1 [42].

\section{Results}

\subsection{Variation of ITS sequences}

Comparative analysis of the Cladonia rei ITS sequences revealed the presence of 19 haplotypes overall, which are distinguished by 49 variable sites. Haplotype composition, relative frequency, and distinctive characteristics are shown in Table 4. There are several most frequent haplotypes that differ from each other significantly (haplotypes 2, 4, and 12), while eleven of them are represented by single individuals only. The minimum spanning tree (Figure 1) illustrates the relative frequency of each haplotype and the distance between each of them measured by the number of evolutionary events. Haplotype 2 is placed in the central position of the tree. Seven haplotypes are generally closely connected by relatively short branches to haplotype 2 (one to four mutational steps). Haplotypes 5 and 16 proved to be the most distinctive. The longest branch found in the ITS haplotype network was 12 steps long. Mapping of haplotypes based on the minimum spanning

\begin{tabular}{|c|c|c|c|}
\hline Feature & Unit/scale & Number of materials & Method \\
\hline Podetium width & $\mathrm{mm}$ & & stereoscopic microscope \\
\hline Inner and outer medulla thickness & $\mu \mathrm{m}$ & $\begin{array}{l}\mathrm{n}=15(5 \text { podetia per specimen, } 3 \\
\text { measurements per podetium) }\end{array}$ & $\begin{array}{l}\text { transverse sections prepared } \\
\text { using a Leica CM1850UV } \\
\text { freezing apparatus, stained with a } \\
\text { lactophenol blue solution, examined } \\
\text { under a light microscope }\end{array}$ \\
\hline Soredia size & $\mu \mathrm{m}$ & $\begin{array}{c}n=50 \text { (5 podetia per specimen, } 10 \\
\text { soredia per podetium) }\end{array}$ & light microscope \\
\hline Podetial squamules & $\begin{array}{c}\text { 0-absent } \\
\text { 1-sparse } \\
\text { 2-numerous }\end{array}$ & & \\
\hline $\begin{array}{l}\text { Cortex at the base of podetia; Scyphi } \\
\text { at the podetial apex; Apothecia }\end{array}$ & $\begin{array}{l}0 \text {-absent } \\
1 \text {-present }\end{array}$ & specimen & stereoscopic microscope \\
\hline Branching type & $\begin{array}{l}\text { 1-simple } \\
\text { 2-multiple }\end{array}$ & & \\
\hline
\end{tabular}

Table 3. The list of examined characters together with unit/scale and the number of materials as well as methods used for particular measurements and observations. 

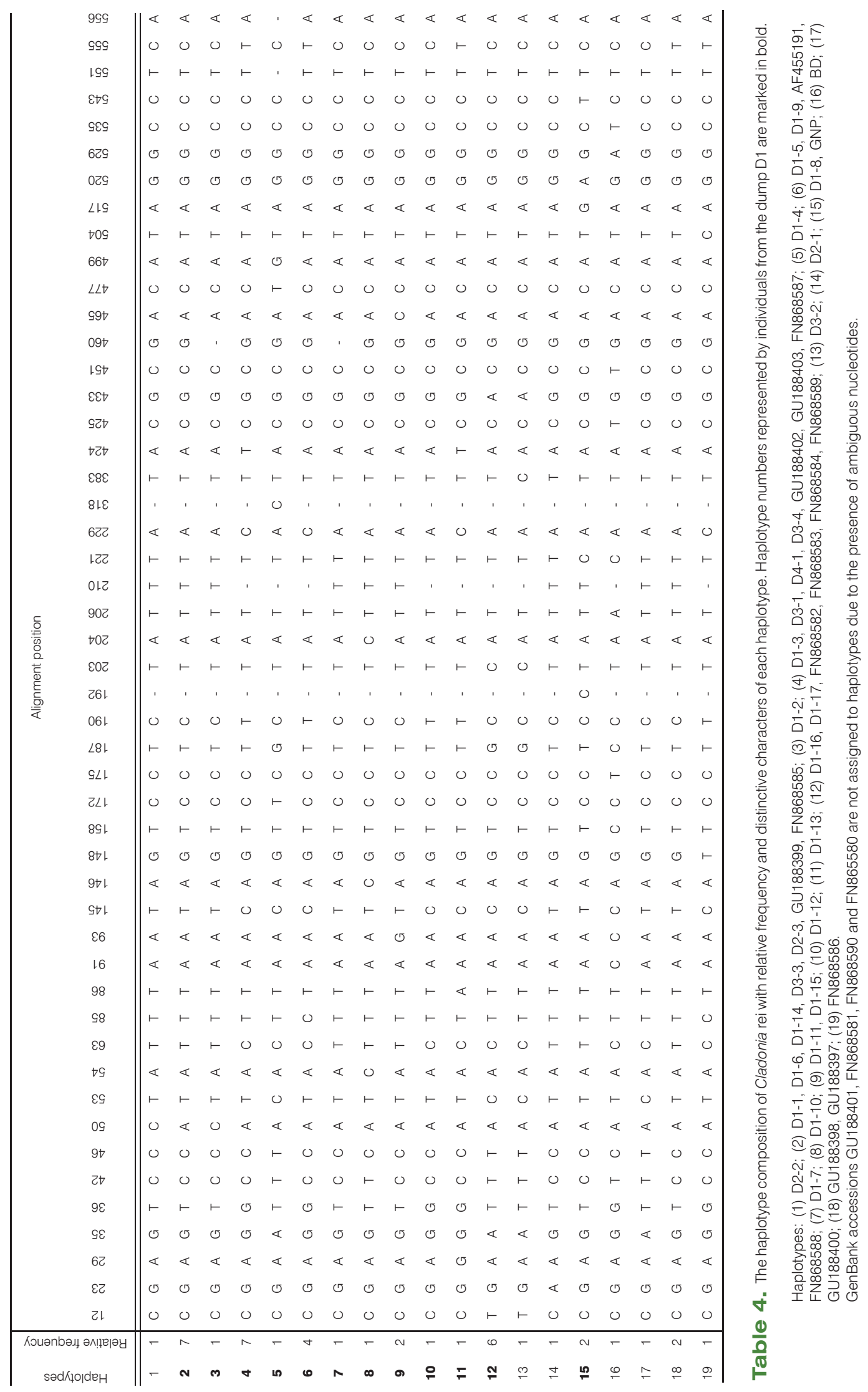


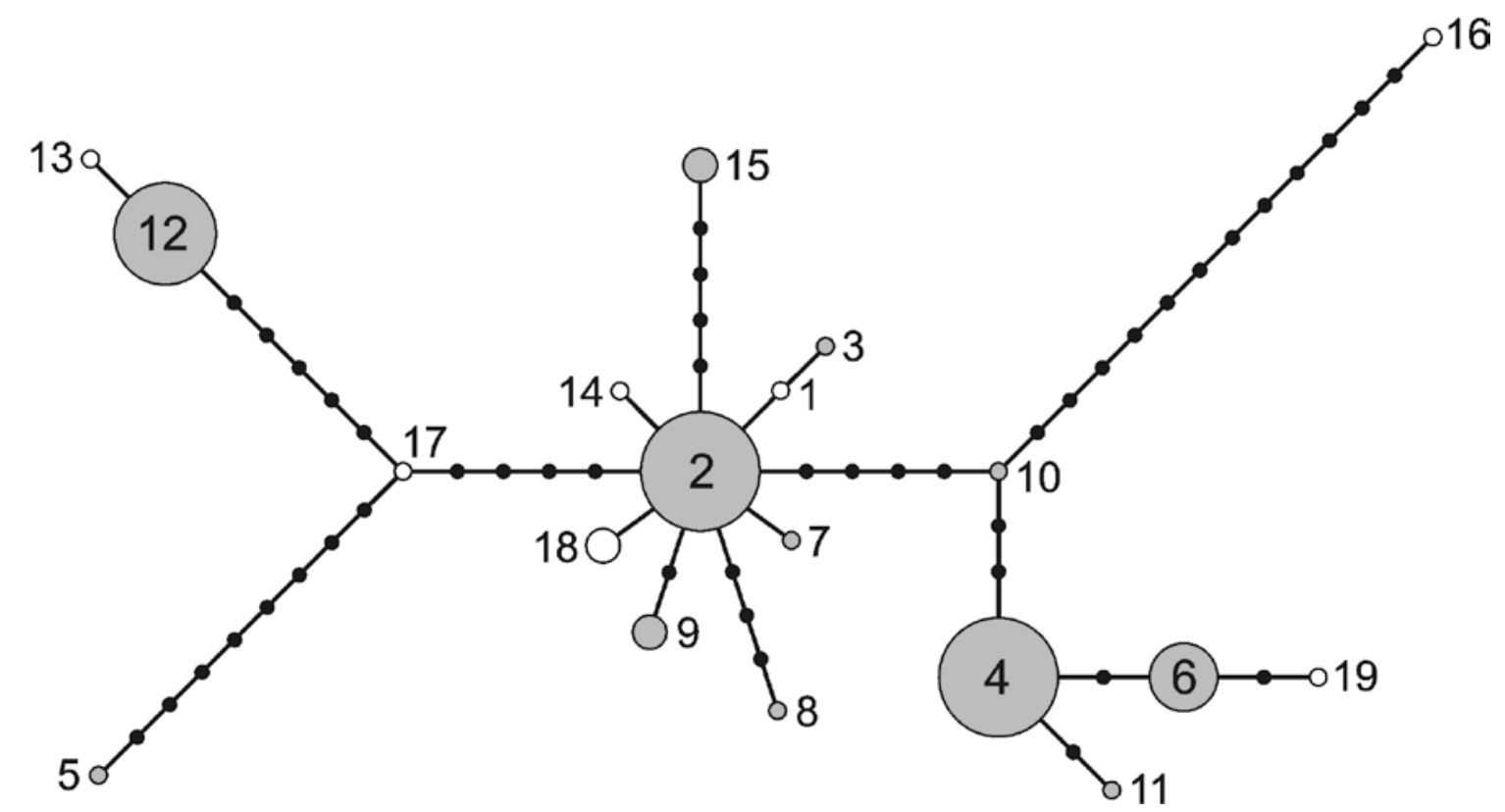

Figure 1. The minimum spanning tree for Cladonia rei haplotypes based on ITS sequences. Varying numbered circle areas correspond to the relative haplotype frequency in the analyzed data set. Gray circles represent haplotypes from the dump D1; small black circles represent the mutational steps between haplotypes.

tree did not reveal any clear geographic patterns. Twelve of the recorded haplotypes (marked in bold in Table 4) are present in the population from dump D1, including the three most frequent haplotypes. This indicates high genetic variation within a single population of $C$. rei.

\subsection{Phylogenetic analysis}

The ITS-based Bayesian phylogeny of our samples combined with external GenBank sequences is shown in Figure 2. The position of Cladonia rei within the section's tree is relatively well defined, as it forms most of the strongly supported but unresolved major clade. This group is flanked by five sequences of closely related C. fimbriata that are arranged in paraphyletic manner where the specimen AF455224 forms its own weekly supported branch, which is closer to the $C$. rei clade. This is exactly the same pattern as in the tree provided by Dolnik et al. [17]. Nevertheless, two sequences of seemingly unrelated species, C. corniculata (AF455201) and $C$. subsquamosa (AF455225), surprisingly join the C. reispecies, as they form two first unresolved branches along with the C. rei clades A, B, and C. The analysed $C$. reisequences are grouped into three distinct lineages, marked here as clade A, clade B (with subclades B, B', and $\left.B^{\prime \prime}\right)$, and clade $C$. Each clade includes sequences of specimens originating from dump D1.

The strongly supported clade A comprises 18 almost exclusively Polish specimens, including nine originating from dump D1 and four from the surrounding dumps. The only exception is one Spanish specimen (FN868585). Some additional variously supported connections were revealed within this clade (Figure 2), namely the pairs of C. rei D2-2 / C. rei D1-2, C. rei D1-11 / C. rei D1-15, and C. rei GU118398 / C. rei GU188297 were revealed.

The weakly supported clade $B$ is composed of three subclades: $B^{\prime}$, the specimens from the Błędowska desert (BD) and northern Germany (GU188401), B", a single specimen from dump D1 (D1-12), and B, consisting of 13 specimens. Although the branching order of subclades $\mathrm{B}^{\prime}$ and $\mathrm{B}^{\prime \prime}$ is only weakly supported, the support for subclade $B$ is very strong. Subclade B includes four specimens from dump D1 and three specimens from adjacent dumps (D3, D4), as well as specimens from northern Germany (GU188402, GU188403), the Czech Republic (FN868587, FN868588), Spain (FN868586), and Nova Scotia, Canada (AF455191). This subclade is subsequently divided into two strongly supported groups (Figure 2).

Clade $C$ is very strongly supported, and a Danish specimen (GU188400) and a specimen from dump D1 (D1-4) form two branches along the stem of an unresolved group of ten sequences. The unresolved group within clade $C$ is very geographically diverse, including specimens from dumps D1 and D3, the Czech Republic (FN868581, FN868589), the Netherlands (FN868590), the USA (FN868584), Canada (FN868580, FN868583), and Norway (FN868582). 


\subsection{Morphology and chemistry}

The dendrogram of the entire data set, based on the cluster analysis results (Figure 3 ), shows two distinct clusters, each of which is highly diverse. None of the clusters refer to the clades obtained on the basis of molecular data. Similarly, none of the designated haplotypes form a clearly distinct group. According to the results of PCoA (Figure 4), the first two coordinates accounted for $53.4 \%$ of the total variance; the first explains $37.9 \%$ of the variation, the second $15.4 \%$. The PCoA ordination diagram showed that the examined specimens do not form distinctly separated groups. Nevertheless, a group of points concentrated on the right side of the scatter plot can be distinguished (Figure 4). Numerous and densely packed squamules on podetia, the absence of apothecia and scyphi, the presence of distinct cortex at the podetium base, and relatively thick podetium walls are responsible for this PCoA result. Consequently, in addition to a full range of known Cladonia rei morphotypes, a new morphotype was recognised. However, representatives of the new morphotype do not create a monophyletic group, and importantly, the results of morphometric analyses generally do not coincide with the phylogenetic clades obtained. Nevertheless, it is noteworthy that all individuals representing haplotype 2 are associated with the new morphotype.

The individuals within particular clades display a large range of morphological variability. The analysis of variance (ANOVA) did not show any significant differences between particular clades in terms of all examined continuous morphological characteristics,

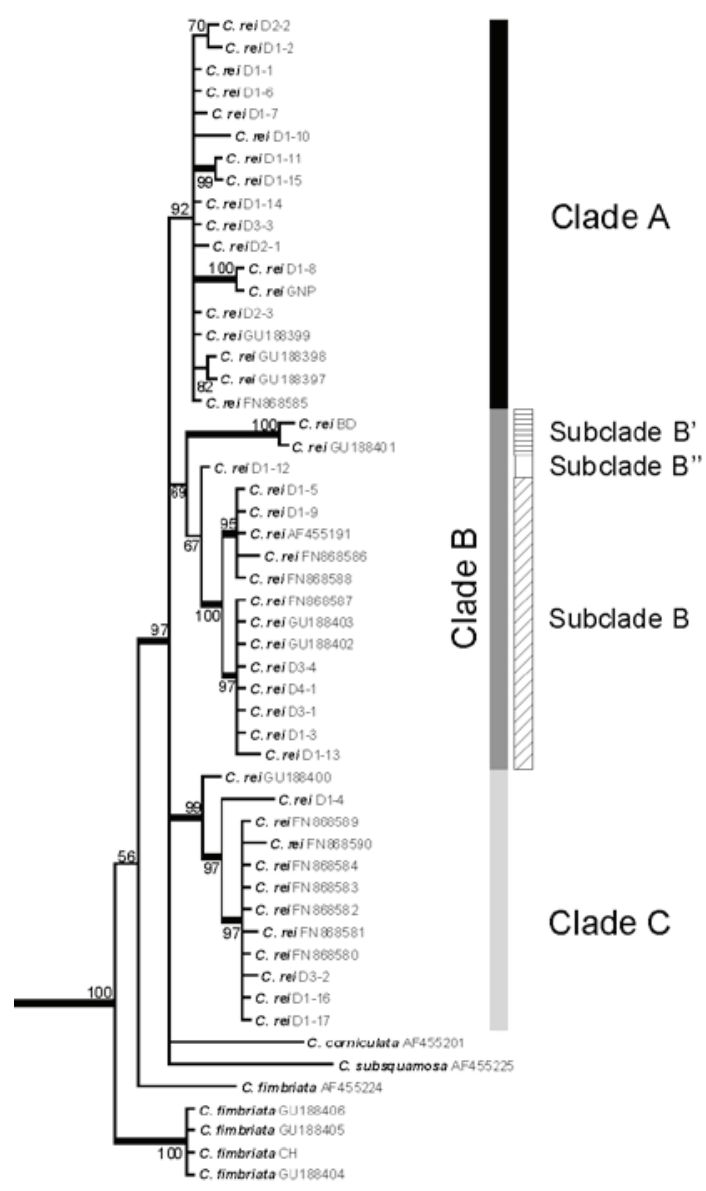

Figure 2. The results of $50 \%$ majority rule Bayesian analysis of all sequenced and GenBank-sourced ITS sequences of section Cladonia. Only C. rei and C. fimbriata clades are shown. Bold branches indicate posterior probability support $\geq 95 \%$.

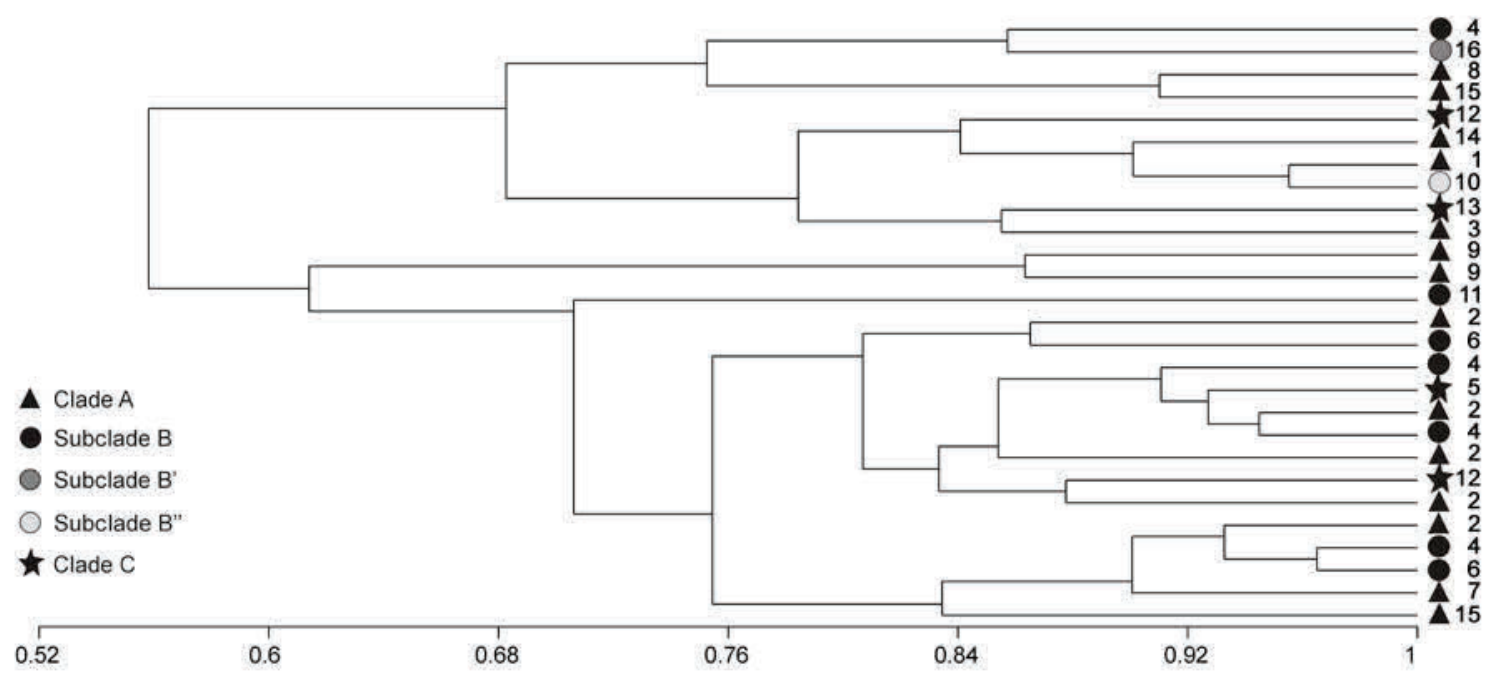

Figure 3. Dendrogram presenting the result of cluster analysis (UPGMA method of classification and Gower's general similarity coefficient) showing similarities between examined specimens of Cladonia rei. Affiliations of particular specimens to designated clades and subclades (symbols) and haplotypes (numbers) are given. 


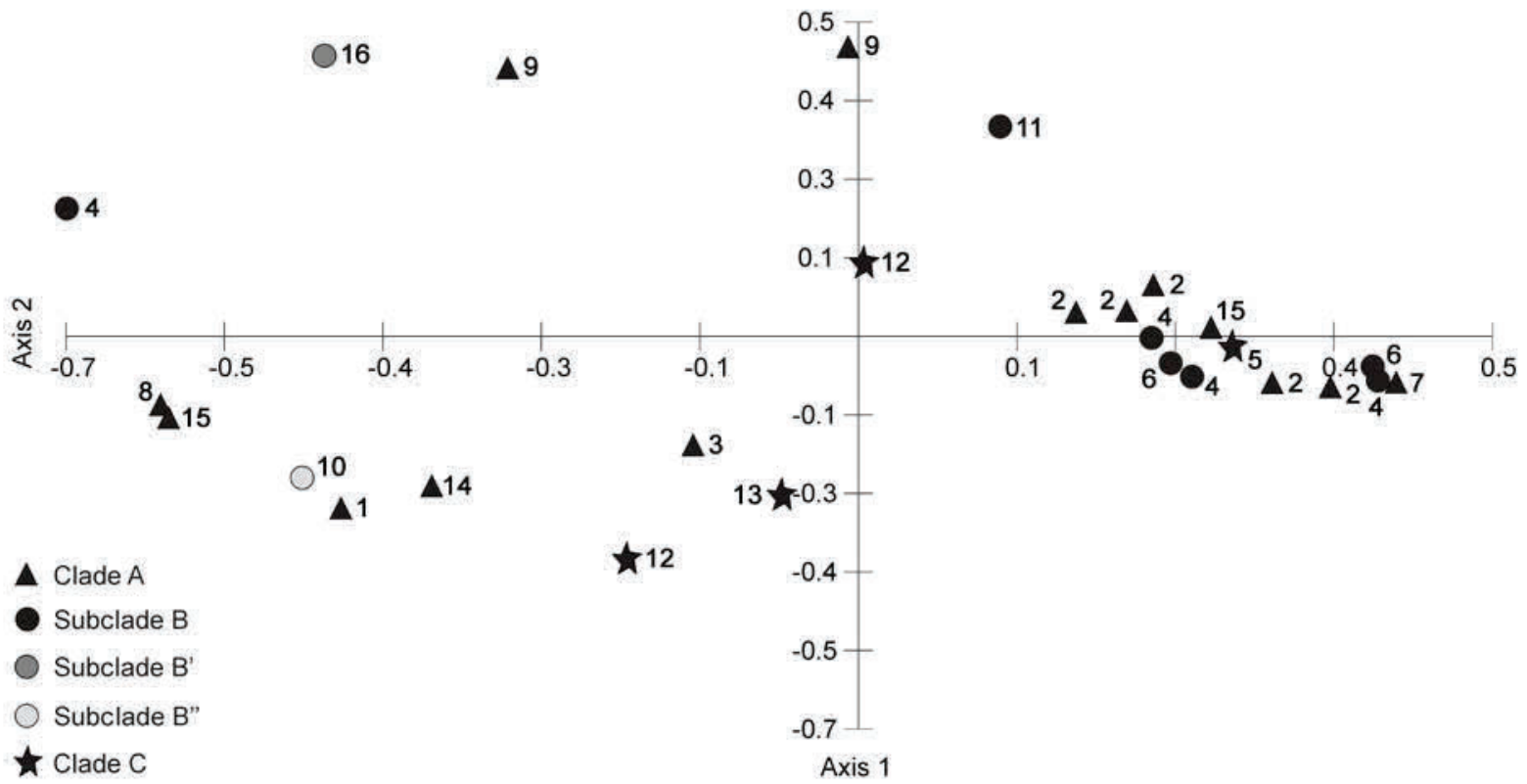

Figure 4. Scatter plot presenting the results of principal coordinate analysis (PCOA) of individual specimens of Cladonia rei along axis 1 and axis 2. Affiliations of particular specimens to designated clades and subclades (symbols) and haplotypes (numbers) are given.

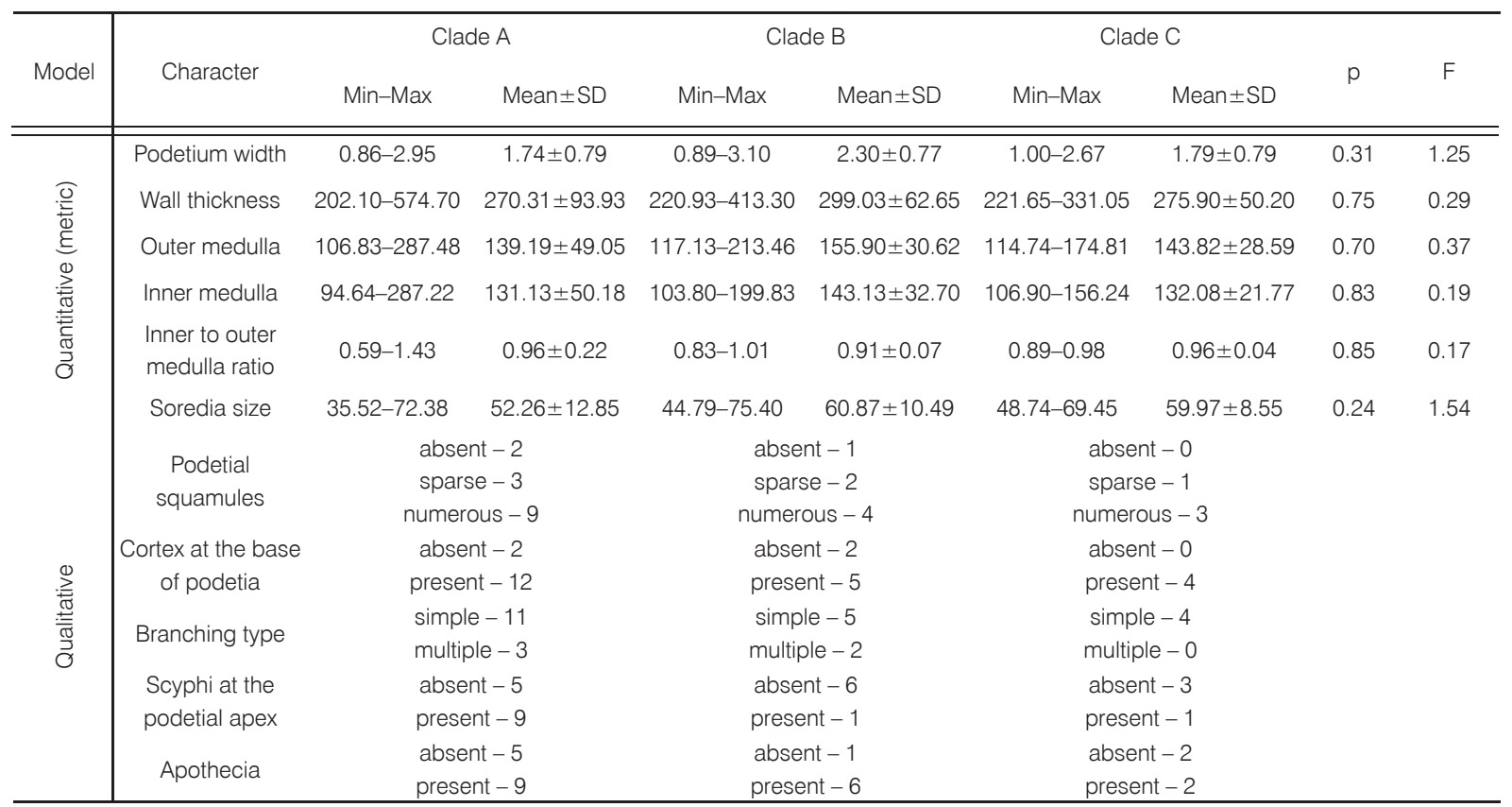

Table 5. Quantitative and qualitative characters for three clades of Cladonia rei. For quantitative characters: Mean - arithmetical mean; SD standard deviation; Min - minimum value; Max - maximum value. Results of variance analysis ANOVA $(p<0.05)$ : $F$ and $p$ values for each character. For qualitative characters the number of recorded specimens with particular status of the character are given.

and the $p$ value was much higher than the critical value (see Table 5).

Two main chemical races of Cladonia rei were detected. Ten samples of $C$. rei contained homosekikaic acid together with fumarprotocetraric acid (usually as a complex with related acids; chemotype I), while 18 samples contained only homosekikaic acid (chemotype II). In both cases, homosekikaic acid was accompanied 
by small amounts of sekikaic acid. None of the chemotypes are specific to a certain clade. Even though the samples originating from post-smelting dumps and located in clade $\mathrm{C}$ belong to chemotype II, this clade includes also specimens representing chemotype I from other parts of the world.

\section{Discussion}

Little is known about the population-level genetic variation of lichen-forming fungi; in particular, there are very few studies concerning species that colonise anthropogenic and disturbed habitats. The reaction of lichens to anthropogenic stress seems interesting, especially given that genetic variation is generally assumed to be important for a species to adapt to new habitats [43]. On the other hand, it could be also assumed that environmental stress causes propagation to be primarily vegetative and thus the genetic diversity in such populations will remain low (see also $[7,44]$ ). Furthermore, a high degree of genetic differentiation between lichen populations in different habitats was found (e.g. [8]), which suggests that intraspecific differentiation is correlated with ecological properties of the species. Studies dealing with lichens growing on metal-polluted substrates often discuss the possible existence of populations that are strongly adapted to heavy metal contamination (e.g. [3]). However, this discussion is based entirely on observations on morphology and ecology without unambiguous evidence of adaptation (see also [8]).

In the present study, the extent of genetic variability of Cladonia rei from the post-smelting dump was investigated to provide an indication of whether or not variation was present within populations of this lichen. One of the most commonly used sequences in lichen population genetics is the ribosomal DNA (rDNA) marker, mainly the internal transcribed spacer (ITS) [6]. Only the ITS region of the mycobiont was found to be sufficient to assess the high genetic population variability. The number of haplotypes in the examined population reached as many as 12 . Some of the examined specimens represent haplotypes with unique sequences and some of the haplotypes differ significantly from each other (maximum 24 mutational steps). Bearing in mind that only one kind of rDNA marker was analysed, such a degree of genetic variation is surprisingly high. It is difficult to compare our results with other studies on genetic structure, as different markers have been used, various spatial scales have been considered, and different taxonomic groups have been included (see [6]). Studies of genetic variation at the population level in the fungal component of Cladonia representatives have primarily been conducted using restriction site patterns of the nuclear ribosomal small subunit RNA gene (nrSSU) [45-47]. In the Cladonia chlorophaea complex, 13 genotypes were found within a single population [48]. On the other hand, in Cladonia subtenuis no variation in the nrSSU was found within a population [47]. In fact, the real causes of genetic diversity in lichens depend on various factors, such as taxonomic affinity, reproductive mode, life history, mating system, and habitat parameters (e.g. [7,8,49,50]). Nevertheless, our work provides evidence of the very high genetic variability of $C$. rei inhabiting a very limited area of one post-smelting dump.

The phylogenetic analysis revealed three strongly supported Cladonia rei clades. Each of them includes specimens from different geographic regions. For example, samples from various countries of Europe and North America appear in clades B and C. On the other hand, samples from the single population are split; they are found in all three clades are often very closely related to samples from distant parts of the world. According to previous studies, genetic patterns based on ITS sequences also failed to correlate with the geographical origin of $C$. rei specimens $[17,23]$. Our results undoubtedly proved that the study area is characterised by high genetic diversity of the species, which suggests that that none of the determined haplotypes represents an ecotype specific to metal-contaminated habitats. Nevertheless, high genetic diversity can be considered to be an attribute of a coloniser species.

Apart from high genetic variability, individuals of Cladonia rei from post-smelting dumps demonstrate great phenotypic variability. A wide range of morphological forms was observed (see also $[15,17,23]$ ), with additional specific 'robust/squat' morphotype. However, none of the morphotypes revealed by morphometric analyses correlate with phylogenetic clades. Environmental conditions often modify the organisation and structure of lichen thalli. This is especially true for Cladonia representatives, which have been shown to have high phenotypic plasticity, and whose morphological variability is often induced by habitat factors (see e.g. [51-53]).

High genetic variation is generally assumed to be important for a species to adapt to new habitats and enhance its survival probability, particularly in changing environments $[43,54,55]$. Such populations are expected to have a higher evolutionary potential [56]. Cladonia rei is widely distributed in Europe and can generally be considered a cosmopolitan lichen $[15,16]$. The species is widespread in Poland and its localities occur in semi-natural and natural habitats in the vicinity of the examined dumps; however, it 
does not create large populations there (Osyczka and Rola, unpublished data, [57]) as it does in extremely contaminated post-smelting dumps [25]. High tolerance to anthropogenic habitats, great phenotypic plasticity, and high production of various types of propagules undoubtedly contribute to its successful colonisation of post-smelting slag dumps. The spontaneous and rapid appearance of $C$. rei is additionally favoured by weak competition from other organisms [25] (see also [58]), which are limited by highly adverse habitat factors (see Table 1; [29]). Furthermore, the recently described restrained heavy-metal accumulation pattern of $C$. rei may be of great importance for adaptation to contaminated areas [26]. High genetic variability within a single population

\section{References}

[1] Fernández-Mendoza F., Domaschke S., García M.A., Jordan P., Martín M.P., Printzen C., Population structure of mycobionts and photobionts of the widespread lichen Cetraria aculeata, Mol. Ecol., 2011, 20, 1208-1232

[2] Gilbert O., The lichen flora of urban wasteland, Lichenologist, 1990, 22, 87-101

[3] Purvis O.W., Halls C., A review of lichens in metalenriched environments, Lichenologist, 1996, 28, 571-601

[4] Pino-Bodas R., Martín M.P., Burgaz A.R., Lumbsch. H.T., Species delimitation in Cladonia (Ascomycota): a challenge to the DNA barcoding philosophy, Mol. Ecol., 2013

[5] DePriest P.T., Early molecular investigations of lichen-forming symbionts: 1986-2001, Annu. Rev. Microbiol., 2004, 58, 273-301

[6] Werth S., Population genetics of lichen-forming fungi - a review, Lichenologist, 2010, 42, 499-519.

[7] Zoller S., Lutzoni F., Scheidegger C., Genetic variation within and among populations of the threatened lichen Lobaria pulmonaria in Switzerland and implications for its conservation, Mol. Ecol., 1999, 8, 2049-2059

[8] Lindblom L., Ekman S., Genetic variation and population differentiation in the lichen-forming ascomycete Xanthoria parietina on the island Storfosna, central Norway, Mol. Ecol., 2006, 15, 1545-1559

[9] Loveless M.D., Hamrick J.L., Ecological determinants of genetic structure of plant populations, Ann. Rev. Ecol. Syst., 1984, 15, 65-95 from dump D1 suggests that many genotypes can colonise the dumps, demonstrating the great potential of $C$. rei to colonise such anthropogenic habitats. All the aforementioned attributes indicate that the mass occurrence of $C$. rei in post-smelting dumps is not accidental and emphasise its role as an important pioneer in the early stages of natural regeneration of disturbed sites.

\section{Acknowledgements}

The project was financially supported by the National Science Centre (Decision No. DEC-2012/05/N/ NZ8/00842).

[10] Robertson J., Piercey-Normore M.D., Gene flow in symbionts of Cladonia arbuscula, Lichenologist, 2007, 39, 69-82

[11] Stenroos S., Hyvönen J., Myllys L., Thell A., Ahti T., Phylogeny of the genus Cladonia s. lat. (Cladoniaceae, Ascomycetes) inferred from molecular, morphological, and chemical data, Cladistics, 2002, 18, 237-278

[12] Pino-Bodas R., BurgazA.R., Martín M.P. \& Lumbsch H.T., Species delimitations in the Cladonia cariosa group (Cladoniaceae, Ascomycota), Lichenologist, 2012, 44, 121-135

[13] DePriest P.T., Small subunit rDNA variation in a population of lichen fungi due to optional group-I introns, Gene, 1993a, 134, 67-74

[14] Beard K.H., DePriest P.T., Genetic variation within and among mats of the reindeer lichen, Cladina subtenuis, Lichenologist, 1996, 28, 171-182

[15] Syrek M., Kukwa M., Taxonomy of the lichen Cladonia rei and its status in Poland, Biologia, 2008, 63, 493-497

[16] James P.W., Cladonia P. Browne (1756), In: Smith C.W., Aptroot A., Coppins B.J., Fletcher A., Gilbert O.L., James P.W., et al., (Eds.), The lichens of Great Britain and Ireland, The British Lichen Society, London, 2009

[17] Dolnik C., Beck A., Zarabaska D., Distinction of Cladonia rei and C. subulata based on molecular, chemical and morphological characteristics, Lichenologist, 2010, 42, 373-386

[18] Paus S.M., Epigeic lichen vegetation in Northwest Germany and adjacent areas [Die Erdflechtenvegetation Nordwestdeutschlands und 
einiger Randgebiete], Biblioth. Lichenol., 1997, 66, 1-222, (in German)

[19] Hajdúk J., Lisická E., Cladonia rei (lichenizované askomycéty) na stanovištiach kontaminovaných imisiami z Kovohút Krompachy (SV Slovensko), Bull. Slov. Bot. Spoločn. Bratislava, 1999, 21, 49-51

[20] Gilbert O., Lichens, New Naturalist Library, Harper Collins Publishers, London, 2000

[21] Cuny D., Denayer F.O., Foucault de B., Schumacker R., Colein P., Van Haluwyn C., Patterns of metal soil contamination and changes in terrestrial cryptogamic communities, Environ. Pollut., 2004, 129, 289-297

[22] Rajakaruna N., Harris T.B., Clayden S., Dibble A., Olday F.S., Lichens of Callahan Mine, a copper and zinc-enriched Superfund site in Brooksville, Maine, U.S.A., Rhodora, 2011, 113, 1-31

[23] Pino-Bodas R., Burgaz A.R., Martín M.P., Elucidating the taxonomic rank of Cladonia subulata versus C. rei (Cladoniaceae), Mycotaxon, 2010, 113, 311-326

[24] Kukwa M., New or interesting records of lichenicolous fungi from Poland III, Herzogia, 2005, 18, 37-46

[25] Osyczka P., Rola K., Cladonia lichens as the most effective and essential pioneers in strongly contaminated slag dumps. Cent. Eur. J. Biol., 2013, 8, 876-887

[26] Osyczka P., Rola K., Response of the lichen Cladonia rei Schaer. to strong heavy metal contamination of the substrate, Environ. Sci. Pollut. Res., 2013, 20, 5076-5084

[27] Maciak F., The protection and restoration of the environment [Ochrona i rekultywacja środowiska], Szkoła Główna Gospodarstwa Wiejskiego, Warsaw, 1996 (in Polish)

[28] Puziewicz J., Zainoun K., Bril H., Primary phases in pyrometallurgical slags from a zinc-smelting waste dump, Świętochłowice, Upper Silesia, Poland, Can. Mineral., 2007, 45, 1189-1200

[29] Skubała K., Vascular flora of sites contaminated with heavy metals on the example of two post-industrial spoil heaps connected with manufacturing of zinc and lead products in Upper Silesia, Arch. Environ. Prot., 2011, 37, 55-74

[30] Gardes M., Bruns T.D., ITS primers with enhanced specificity for basidiomycetes - application to the identification of mycorrhizae and rusts, Mol. Ecol., 1993, 2, 113-118

[31] White T.J., Bruns T., Lee S., Taylor J.W., Amplification and direct sequencing of fungal ribosomal RNA genes for phylogenetics, In: Innis
M.A., Gelfand D.H., Sninsky J.J., White T.J. (Eds.), PCR Protocols: A Guide to Methods and Applications, Academic Press, New York, 1990

[32] Thompson J.D., Higgins D.G., Gibson T.J., CLUSTAL W: improving the sensitivity of progressive multiple sequence alignment through sequence weighting, position specific gap penalties and weight matrix choice, Nucl. Acids Res.,1994, 22, 4673-4680

[33] Tamura K., Peterson D., Peterson N., Stecher G., Nei M., Kumar S., MEGA5: molecular evolutionary genetics analysis using maximum likelihood, evolutionary distance, and maximum parsimony methods, Mol. Biol. Evol., 2011, 28, 2731-2739

[34] Simmons M.P., Ochoterena H., Gaps as characters in sequence-based phylogenetic analyses, Syst. Biol., 2000, 49, 369-381

[35] Borchsenius F., FastGap 1.2, Department of Biosciences, Aarhus University, Denmark. Published online at http://www.aubot.dk/FastGap_ home.htm (accessed 18.03.2013)

[36] Hulsenbeck J.P., Ronquist F., MrBayes: Bayesian inference of phylogeny, Bioinformatics, 2001, 17, 754-755

[37] Excoffier L., Laval G., Schneider S., Arlequin ver. 3.0: An integrated software package for population genetics data analysis, Evol. Bioinform., 2005, 1, 47-50

[38] Rohlf F.J., Algorithm 76. Hierarchical clustering using the minimum spanning tree, Computer J., 1973, 16, 93-95

[39] Teacher A.G.F., Griffiths D.J., HapStar: Automated haplotype network layout and visualization, Mol. Ecol. Resour., 2011, 11, 151-153

[40] Orange A., James P.W., White F.J., Microchemical Methods for the Identification of Lichens, British Lichen Society, London, 2001

[41] Sokal R.R., Sneath P.H., Principles of numerical taxonomy, W.H. Freeman, San Francisco, 1963

[42] Kovach W.L., MVSP - A Multivariate Statistical Package for Windows, ver. 3.1, Kovach Computing Services, Pentraeth, 1999

[43] Mitton J.B., Grant M.C., Associations among protein heterozygosity, growth rate, and developmental homeostasis, Annu. Rev. Ecol. Syst., 1984, 15, 479-499

[44] Lynch M., A quantitative-genetic perspective on conservation issues, In: Avise J.C., Hamrick J.L. (Eds.), Conservation Genetics, Case Histories from Nature, Chapman \& Hall, New York, 1996

[45] DePriest P.T., Been M.D., Numerous group I introns with variable distributions in the ribosomal DNA of a lichen fungus, J. Mol. Biol., 1992, 228, 315-321 
[46] DePriest P.T., Molecular innovations in lichen systematics: the use of ribosomal and intron nucleotide sequences in the Cladonia chlorophaea complex, Bryologist, 1993b, 96, 314-325

[47] Beard K.H., DePriest P.T., Genetic variation within and among mats of the reindeer lichen, Cladina subtenuis, Lichenologist, 1996, 28, 171-182

[48] DePriest P.T., Variation in the Cladonia chlorophaea complex II: ribosomal DNA variation in a Southern Appalachian population, Bryologist, 1994, 97, 117-126

[49] Dyer P.S., Murtagh G.J., Variation in the ribosomal ITS-sequence of the lichens Buellia frigida and Xanthoria elegans from the Vestfold Hills, eastern Antarctica, Lichenologist, 2001, 33, 151-159

[50] Crespo A., Molina M.C., Blanco O., Schroeter B., Sancho L.G., Hawksworth D.L., rDNA ITS and -tubulin gene sequence analyses reveal two monophyletic groups within the cosmopolitan lichen Parmelia saxatilis, Mycol. Res., 2002, 106, 788-795

[51] Ahti T., Cladoniaceae, Flora Neotropica Monograph 78, New York Botanical Garden Press, New York, 2000

[52] Osyczka P., Flakus A., Węgrzyn M. \& Cykowska B., Cladonia crispata var. cetrariiformis (Cladoniaceae, lichenized Ascomycota) in the Tatra Mts., Biologia, 2007, 62, 144-147
[53] Osyczka P., Rola K., Phenotypic plasticity of primary thallus in selected Cladonia species (lichenized Ascomycota: Cladoniaceae), Biologia, 2013, 68, 365-372

[54] Wildt D.E., Bush M., Goodrowe K.L., et al., Reproductive and genetic consequences of founding isolated lion populations, Nature, 1987, 324, 328-331

[55] Hedrick P.W., Miller P.S., Conservation genetics. Techniques and fundamentals, Ecol. Appl., 1992, 2, 30-46

[56] Avise J.C., Molecular Markers. Natural History and Evolution, Chapman \& Hall, New York, 1994

[57] Szarek-Łukaszewska G., Vegetation of reclaimed and spontaneously vegetated $\mathrm{Zn}-\mathrm{Pb}$ mine wastes in Southern Poland, Pol. J. Environ. Stud., 2009, 18, 717-733

[58] Bačkor M., Fahselt D., Physiological attributes of the lichen Cladonia pleurota in heavy metal-rich and control sites near Sudbury (Ontario, Canada), Environ. Exp. Bot., 2004, 52, 149-159

[59] Rola K., Osyczka P., Nobis M., Effect of specific slag substrate properties on pioneer community structure in post-industrial habitats, Community Ecol., under review

[60] Osyczka P., A morphometric evaluation of the Cladonia chlorophaea group and allied taxa (Cladoniaceae, Ascomycota), Herzogia, 2013, 26, 49-64 